\title{
REVIEW
}

\section{NURSES' ROLE IN PROMOTING RELATIONS BETWEEN PARENTS AND PREMATURE NEWBORNS IN ACCORDANCE WITH THE CONCEPT OF FAMILY-CENTERED CARE}

\author{
Kateřina Jakšová1, Lucie Sikorová ${ }^{2}$, Michal Hladík ${ }^{3}$ \\ ${ }^{1}$ General Practitioner Ltd., Czech Republic \\ ${ }^{2}$ Department of Nursing and Midwifery, Faculty of Medicine, University of Ostrava, Czech Republic \\ ${ }^{3}$ Department of Paediatrics, University Hospital Ostrava, Czech Republic
}

Received December 31, 2015; Accepted February 8, 2016. Copyright: This is an open access article distributed under the terms of the Creative Commons Attribution International License (CC BY). http://creativecommons.org/licenses/by/4.0/

\begin{abstract}
Aim: The aim of the following review is to analyze the role of nurses in promoting relations between parents and premature newborns according to the concept of Family-centered care. Design: The type of study - review. Methods: Both licensed and free-access electronic databases were used to search relevant studies from Czech and foreign sources for the period 20002015: CINAHL EBSCOhost, SCOPUS, PubMed and Medline. The selection criteria for the studies to be analyzed were as follows: both quantitative and qualitative studies taking into account parents aged 19-44 with premature newborns from 24-36 weeks of gestation. Experimental studies and imprecisely defined studies were eliminated. Only 21 of the 49 research studies considered met the selection criteria. This review involves seven of the studies: three quantitative studies - one randomized study, two cross-sectional studies, and four case studies. Results: Based on analysis of the studies, it appears that Familycentered care should be considered an essential means of support for parents of premature newborns. The role of nurses in promoting relations between parents and their premature newborns was highly appreciated in the areas of therapeutic communication, efficient work organization and choice of appropriate interventions. Conclusion: Studies focusing on the application of the principles of Family-centered care stress its advantages for parents, premature newborns, and medical staff. The conclusion of most of the studies is that nurses play a unique role in eliminating the degree of trauma experienced by parents, and in promoting relations between parents and premature newborns according to the concept of Family-centered care.
\end{abstract}

Keywords: premature newborn baby, parents of premature newborns, FCC, CCRU, nurse.

\section{Introduction}

The incidence of newborns with low birth weight in all weight categories is increasing globally (Aagaard, Hall, 2008). The causes are as follows: the growing number of babies born within multiple births, the growing average age of mothers giving birth, including the percentage of mothers giving birth after the age of 35 when the risk of preterm birth is higher, and, finally, the fact that more and more extremely premature babies are surviving - born at 26 weeks of gestation or earlier (Young et al., 2006; Arockiasamy et al., 2008).

While previously the emphasis has been on perfecting the technical aspects of life-saving interventions, today the needs of premature newborns and their parents are increasingly being taken into account (Fendrychová, 2007).

Corresponding author: Kateřina Jakšová, Mlekarenská 1933,
$\begin{aligned} & \text { Rychvald-Podlesí, } \\ & \text { kjaksova@seznam.cz }\end{aligned}$$\quad \begin{gathered}\text { Czech } \\ \text { Republic; }\end{gathered}$
kjaksova@seznam.cz.
Dissatisfaction with traditional attitudes in providing medical care has stimulated the rise of Familycentered care (FCC) - care focused on the family. The core of this concept is the relationship between individual family members and medical staff. In this relationship families are considered to be equal partners in promoting, planning and evaluating care. FCC changes the role of parents from passive recipients to active participants in care (Franck et al., 2005; Hockenbery, Wilson, 2006). This constitutes a holistic approach to care, reflecting a shift from the traditional focus on the biomedical condition of babies to that of regarding them in their family context, with the family as an integral part of the medical team.

The main philosophy of FCC is the importance of the unique and individual needs of every child and family. Within this type of care, parents and medical staff cooperate with each other as equal partners, trying to provide the highest level of care in the best possible conditions for promoting the rise and 
development of individual family members (Neal et al., 2008).

This kind of care places new demands on medical staff, and, as is evident from the sources reviewed, contributes to changes in interpersonal roles. Although the principles of care have been known since the 1950s, FCC remains the object of many studies and research. In their clinical study, Bastani et al. (2015) come to the conclusion that it continues to be poorly implemented in clinical practice, a symptom of which is the constant call to establish training programs for medical and non-medical professionals.

\section{Aim}

The aim was to analyze the role of nurses in promoting relations between parents and premature newborns according to the concept of FCC.

\section{Methods}

\section{Eligibility Criteria}

Based on the research problem, the following selection criteria were chosen: full text specialized studies published in the period from 2000-2015, in reviewed journals. The period of time indicated above is important as substantial changes have been introduced in the implementation of FCC, and, consequently, earlier studies may not necessarily reflect the present state of practice. Abstracts, articles published in other periods of time than those indicated, those published in non-reviewed journals, ethical discussions, and reviews were eliminated.

\section{Sources}

To find relevant resources for the analysis, specialized licensed databases and free-access electronic databases were used: CINAHL EBSCOhost, SCOPUS, PubMed and Medline.

\section{Search}

The following key words were used to search the relevant sources: premature newborn baby, parents of premature newborn baby, FCC, CCRU, nurse. Only 21 of 49 research studies met the criteria.

\section{Study selection and data analysis}

Only seven studies were eventually analyzed and included in the outline: three quantitative studies, one randomized study, two cross-sectional studies, and four qualitative studies - two content analyses and two topical analyses. The process of selection of the studies is shown in figure 1 .

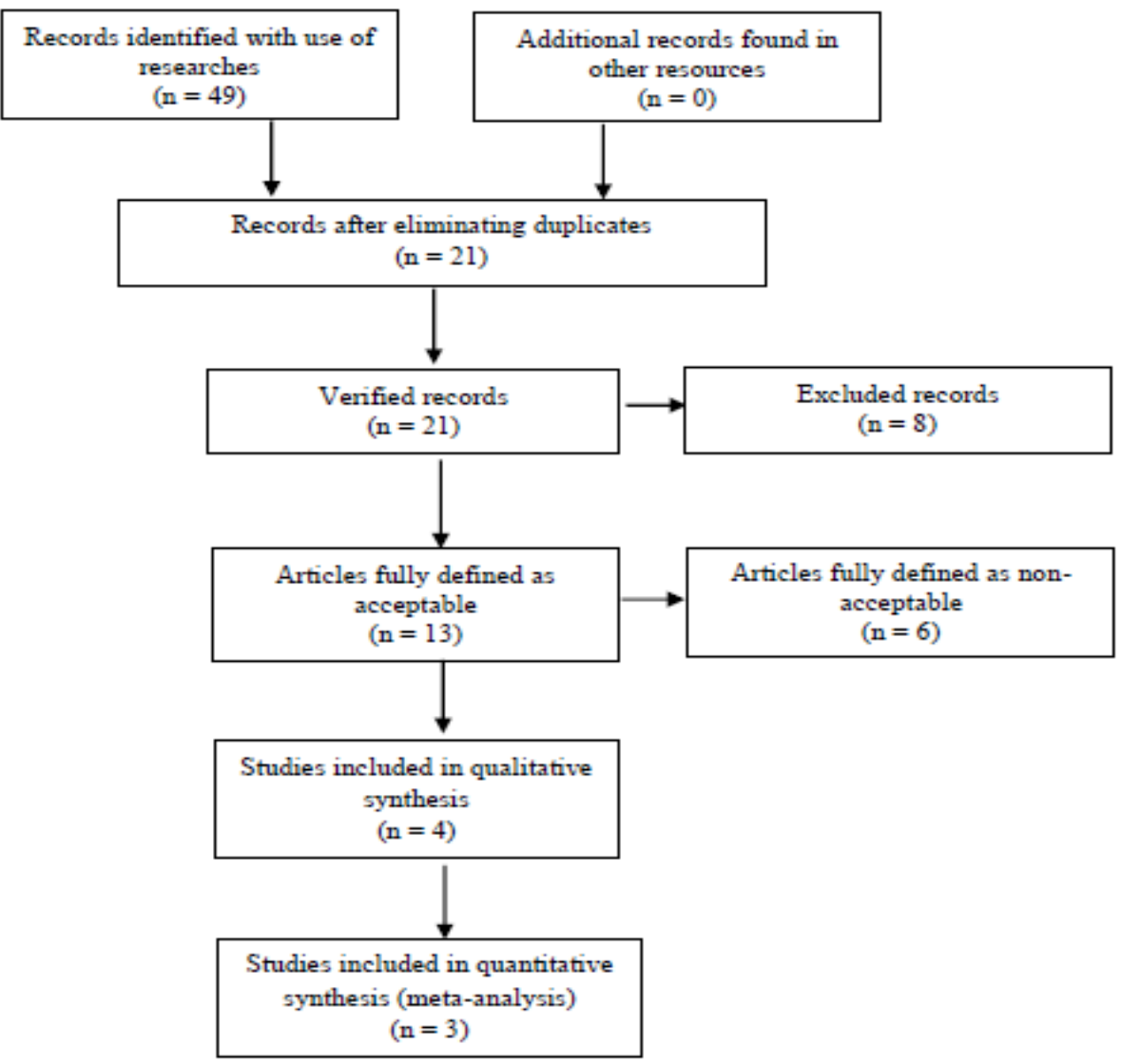

Figure 1 Flow chart - recommendation PRISMA 


\section{Results}

A number of studies have been devoted to the role and status of nurses according to the concept of FCC at Critical Care and Resuscitation Units for newborns. The present situation is analyzed from the point of view of parents and medical staff and the overall benefits for premature newborns are considered. The clinical studies dealt with communicative, organizational, sociocultural and ethical abilities and skills of nurses in the process of the implementation of FCC in practice.

The outline of cited studies complying with the selected criteria is shown in Table 1.

Table 1 Characteristics of clinical studies dealing with the roles of nurses in the concept of FCC

\begin{tabular}{|c|c|c|c|}
\hline Author & Aim & Method & Results \\
\hline Asai (2011) & $\begin{array}{l}\text { To identify the roles of nurses in } \\
\text { the concept of FCC at a CCRU } \\
\text { for newborns in Japan }\end{array}$ & $\begin{array}{l}\text { Quantitative cross }- \\
\text { sectional study of } 710 \\
\text { nurses and } 30 \text { managers of } \\
\text { care }\end{array}$ & $\begin{array}{l}\text { Difficult realisation of nurses' roles } \\
\text { in the process of implementation of } \\
\text { FCC, complicated interaction of } \\
\text { roles of nurses and parents }\end{array}$ \\
\hline Bayley et al. (2013) & $\begin{array}{l}\text { To identify the most common } \\
\text { communication topics between } \\
\text { parents at CCRUs for newborns } \\
\text { and staff }\end{array}$ & $\begin{array}{l}\text { Quantitative study of } 893 \\
\text { nurses working at } \\
\text { neonatology units }\end{array}$ & $\begin{array}{l}\text { Parents' opinions influence the } \\
\text { character of care provided and the } \\
\text { level of contact between nurses and } \\
\text { parents. The communicative role of } \\
\text { nurses according to the principles } \\
\text { of FCC is fundamental. }\end{array}$ \\
\hline Bastani et al. (2015) & $\begin{array}{l}\text { To establish the roles of parents } \\
\text { and nurses in care based on the } \\
\text { principles of FCC }\end{array}$ & $\begin{array}{l}\text { Quantitative randomized } \\
\text { study of } 110 \text { mothers in } \\
\text { the concept of FCC / a } \\
\text { control group of mothers } \\
\text { selected at random in a } \\
\text { standard regime of care }\end{array}$ & $\begin{array}{l}\text { Educational, communicative and } \\
\text { organisational roles of nurses in } \\
\text { providing FCC are irreplaceable. }\end{array}$ \\
\hline Weis et al. (2013) & $\begin{array}{l}\text { To characterize the differences } \\
\text { in experiencing parenthood of } \\
\text { premature newborns according } \\
\text { to the concept of FCC and } \\
\text { within a standard care regime }\end{array}$ & $\begin{array}{l}\text { Qualitative study } \\
\text { thematic analysis }\end{array}$ & $\begin{array}{l}\text { The methods of FCC and } \\
\text { communicative roles of nurses give } \\
\text { the opportunity for better } \\
\text { understanding, mutual interaction, } \\
\text { and cooperation with parents of } \\
\text { premature newborns }\end{array}$ \\
\hline Hurst (2004) & $\begin{array}{l}\text { To identify how informational } \\
\text { and emotional support } \\
\text { stimulates the relation of } \\
\text { mothers to their newborns }\end{array}$ & $\begin{array}{l}\text { Qualitative study - content } \\
\text { analysis }\end{array}$ & $\begin{array}{l}\text { Nurses are able to treat each family } \\
\text { member individually; nurses are } \\
\text { protectors of rights and faciltators } \\
\text { of change }\end{array}$ \\
\hline Finlayson et al. (2014) & $\begin{array}{l}\text { To establish how mothers in } \\
\text { England percieve the role of } \\
\text { nurces according to the concept } \\
\text { of FCC }\end{array}$ & $\begin{array}{l}\text { Qualitative study } \\
\text { thematic analysis }\end{array}$ & $\begin{array}{l}\text { Mothers can see nurses in their } \\
\text { communicative roles involving } \\
\text { interpersonal communication }\end{array}$ \\
\hline Hadian et al. (2015) & $\begin{array}{l}\text { To identify the barriers in } \\
\text { communication between nurses } \\
\text { and parents of premature } \\
\text { newborns according the concept } \\
\text { of FCC }\end{array}$ & $\begin{array}{l}\text { Qualitative study - content } \\
\text { analysis }\end{array}$ & $\begin{array}{l}\text { Eliminating negative factors gives } \\
\text { nurses the chance to fulfill their } \\
\text { communicative roles more } \\
\text { effectively }\end{array}$ \\
\hline
\end{tabular}

\section{Discussion}

The studies by Hurst (2004) and Weis et al. (2013) reveal that after preterm births mothers suffer from anxiety, frustration, helplessness, desperation and uncertainty. The confinement of babies in CCRUs is described by parents as a stressful experience, with negative associations. They commonly refer to the emotional pain, estrangement and anxiety resulting from their being separated from their babies. In this study the authors consistently focus on the role of nurses as the defenders of rights and facilitators of change. They arrive at the conclusion that nurses are able to defend and support parents' roles and effectively cooperate with parents in caring for their babies. They also point out that it is impossible to stick strictly to roles in the concept of FCC. They support this point of view by the fact that parents become actively involved in care together with the staff and thus their roles tend to merge. A qualitative study by Weis et al. (2013), and a study by Hadian et al. (2015), and a qualitative study by Shirazi et al. (2015) stress parents' need for constant updates on 
their newborns' state of health, and the need for open communication with staff and the opportunity to be involved in the care of their own babies. With respect to the observed needs, this study focuses on nurses' communication strategies and skills according to the principles of FCC. In their study the authors describe the main factors influencing communication: the clinical state of newborns, the emotional and working conditions of staff, and the emotional and professional status of the parents. In their conclusion the authors state that economical, psychosocial and sociocultural factors influence interpersonal communication in a quantitative and qualitative way.

Finlayson et al. (2014) together with Bailey et al. (2013) stress in their Swedish study that providing medical care according to the concept of FCC supports parents in their roles, contributing to greater awareness of and more trust in the interventions carried-out. They also point out that being informed and emotionally supported is essential for the family of a premature newborn. Nurses as organizers are able to offer help and organize their work so as to ensure an individual approach to each parent. It is also clear from the studies that this proactive approach is implemented mainly by nurses with higher education or nurses trained in the principles of family care.

Attitudes towards the concept of FCC have also been the subject of many studies. Nurses' points of view have been described by Asai (2011) in his Japanese study. He concludes that nurses usually concede the inevitability and positive impact of involving parents in the care of their preterm newborns, but that they also describe how difficult it is to achieve this in practice. Asai (2011) sees the main reason lying in nurses' contradictory notions of their various roles as specialized care-workers and as those responsible for judging parents' ability to participate in care. Nurses generally prove reluctant to act in accordance with the concept of FCC during invasive interventions at CCRUs.

Young et al. (2006) analyze nurses' attitudes towards the principles of FCC in relation to their level of education. This study confirms the conclusions of Finlayson et al. (2014) and Beily et al. (2013), suggesting that nurses with higher education are more sensitive to the needs of parents and are more conscious of the positives of FCC for a baby and its family. At the same time nurses emphasize the need for communication as a key element in the negotiation of roles between health professionals and parents.

The importance of direct contact between mothers and their newborns is dealt with by Bastani et al.
(2015) in their Iranian study, which demonstrated higher levels of cognitive abilities and skills, better sleep, better neuroedocrinological responses to stress, a more mature autonomic nervous system, and better control of behaviour in preterm newborns in close repeated contact with their parents as compared to babies that had contact with parents under a standard care regime. The authors also tried to discover levels of parental satisfaction with care. They conclude that, for parents, intensive contact, emotional experience and touch are as important as they are for the newborn itself. The parents, conscious of close contact with their baby and participation in care are more open to communication; they more readily accept their new roles and changes than those involved in a standard regime of care. Thus the authors of the study consider the concept of FCC as more open to change and communication. They also highly evaluate the communicative abilities of the staff and the educational and organizational skills of nurses in this system of care.The need for further education for nurses with respect to everyday contact with families of newborns is emphasized by Asai (2011) in his study. He reaches the conclusion that the main role of nurses in accordance with the principles of FCC is to create and maintain interaction between the family of a newborn and staff. Their second role is to acknowledge parents' competencies in the provision of care and contact with their babies. Issues of further education are discussed by Hadian et al. (2015) in his study, focussing on the communicative abilities and skills of nurses. In his opinion the methods of FCC enable nurses and parents to communicate more purposefully. Only after the elimination of sociocultural, psychological, family and economical barriers are nurses able to fulfill their communicative role more effectively according to the concept of FCC.

In the Czech Republic the concept of FCC has not yet been sufficiently elaborated (Sobotková, 2007). There have been individual attempts to apply the principles of FCC in practice, supporting early contact of parents with premature newborns with touching, stroking and kangaroo care. Under current conditions, it is almost impossible to realize all the needs and intervention programs that are essential for the optimal development of babies, and the psychological well-being of mothers and the whole family in CCRUs for newborns and intermediate care units (Vích, 2014). In the Czech Republic, therefore, further training for medical teams in neonatology units is necessary, and should also be extended to psychological and psychosocial services (ChvílováWeberová, 2013). A number of specialists and the 
"Nadace porozumění" (Understanding Foundation) are currently involved in the specialized training of nurses in the principles of FCC in the Czech Republic. The aim is to create a training program for "contact nurses" who will act as guides and mediators in communication between parents and medical staff at neonatology units (Takács et al., 2015).

\section{Limitations of Study}

Only data published in English and found in open access databases and in an electronic form of publication were processed in this review. Data published in other languages were not taken into account.

\section{Conclusion}

FCC is currently considered to be a key concept in the provision of high quality care for premature newborns and their families. The implementation of care remains problematic in some respects all over the world. Firstly, there is the problem of the perception of the roles and competencies of medical staff and parents and also in their expectations of what the nature of this care should be. The emotions of parents of premature newborns have been the subject of many studies. On the one hand, parents are faced with an unexpected parental role, and, on the other hand, they must come to terms with the poor state of health of their newborn. A considerable number of researchers (Hurst, 2004; Hurst, 2006; Vaskelyte et al., 2010; Gooding et al., 2011; Bastani et al., 2015) have concluded that mothers need to be reassured and involved in care. They need physical contact with their newborn and sufficient information from the multidisciplinary medical team, including nurses.

For nurses it is important to realize their own roles and competencies in the process of care. The available studies (Preyde, Ardal, 2003; Hadian et al., 2015; Whelihaen, 2015) reveal that nurses report as the main problems with implementation of the FCC the time and organizational demands of care, its increased workload, complicated paper work and its need for communication skills, allied with fears of exceeding their own competencies and their lack of experience in this area. In particular, nurses are reluctant to act in accordance with the concept of FCC during invasive interventions in CCRUs. As also emerged from the various studies, parents show interest and are willing to be involved in the care of their premature babies. However, they require clear guidance, information and support from nurses. Parents are very interested and willing to be involved in the care of their preterm newborns. However, if expectations and roles are ambiguous, it is stressful both for parents and for medical staff. Nurses require training in communication skills, sufficient resources and the managerial support (Hockenberry, 2006). If these conditions are fulfilled nurses can adequately meet the needs of families, cooperate purposefully with parents and provide optimal nursing care according to the principles of FCC.

\section{Ethical aspects and conflict of interest}

The authors hereby declare that there was no conflict of interest involved in the above research and all ethical aspects were adhered to in the processing of results.

\section{Author contribution}

Conception and design (KJ, LS, MH), data collection $(\mathrm{JK})$, data analysis and interpretation (KJ, LS, MH), processing a manuscript proposal $(\mathrm{KJ})$, supervison (LS, MH), critical correction of the manuscript (KJ, LS, MH).

\section{References}

Aagaard H, Hall EO. Mothers' experiences of having a preterm infant in the neonatal care unit: a meta-synthesis. Journal of Pediatric Nursing. 2008;23(3):e26-36.

Arockiasamy V, Holsti L, Albersheim S. Fathers' experiences in the neonatal intensive care unit: a search for control. Pediatrics. 2008;121(2):e215-222.

Asai H. Predictors of nurses' family-centered care practises in the neonatal intensive care unit. Japan Journal of Nursing Science. 2011;8(1):57-65.

Bailey SM, Hendricks-Munoz KD, Mally P. Parental influence on clinical management during neonatal intensive care: a survey of US neonatologists. Journal of MaternalFetal and Neonatal Medicine. 2013;26(12):1239-1244.

Bastani F, Abadi TA, Haghani H. Effect of Family-Centered Care on improving parental satisfaction and reducing readmission among premature infants: a randomized controlled trial. Journal of Clinical and Diagnostic Research. 2015:9(1):SC4-8.

Fendrychová J, Borek I. Intenzivní péče o novorozence. 1. vyd. Brno: NCONZO; 2007. (in Czech)

Finlayson K, Dixon A, Smith C, Dykes F, Flacking, R. Mothers' perceptions of family centered care in neonatal intensive care units. Sexual \& Reproductive Healthcare: Official Journal of The Swedish Association of Midwives. 2014;5(3):119-124.

Franck LS, Cox S, Allen A, Winter I. Measuring neonatal intensive care unit-related parental stress. Journal of Advanced Nursing. 2005;49(6):608-615.

Gooding JS, Cooper LG, Blaine AI, Franck LS, Howse JL, Berns SD. Family support and family-centered care in the neonatal intensive care unit: origins, advances, impact. Seminars in Perinatology. 2011;35(1):20-28.

Hadian S, Sharif F, Rakhshan M, Pishva N, Jahanpour F. The obstacles against nurse-family communication in family- 
centered care unit. A qualitative study. Journal of Caring Sciences. 2015;4(3):207-216.

Hockenberry MJ, Wilson D. Wong's nursing care of infants and children 8th ed S. Louis: Mosby Elsevier; 2006.

Hurst I. Imposed burdens: a Mexican American mother's experience of family resources in a newborn intensit care unit. Journal of Obstetric, Gynecologic, and Neonatal Nursing. 2004;33(2):156-163.

Hurst I. One size does not fit all: parents' evaluations of a support program in a newborn intensive care nursery. Journal of Perinatal and Neonatal Nursing. 2006;20(3):252261.Chvílová-Weberová M. Realita traumatu rodičů po předčasném porodu, možný vliv na utváření vztahu mezi matkou a dítětem. Neonatologické listy. 2013;19(1):37-40. (in Czech)

Neal A, Frost M, Kuhn J, Green A, Gance-Cleveland B, Kersten R. Family centered care whitin an infant-toddler unit. Pediatric Nursing. 2007;33(6):481-485.

Preyde M, Ardal, F. Effectiveness of a parent "buddy" program for mothers of very preterm infants in a neonatal intensit care. Canadian Medical Assotiation Journal. 2003;168(8):969-973.

Shirazi ZH, Sharif F, Rakhshm M, Pishva N, Jahanpour F. The obstacles against nurse-family communication in FamilyCentered-Care in neonatal intensit care unit: a qualitative study. Journal of Caring Sciences. 2015;4(3):207-216.
Sobotková, I. Psychologie rodiny. 2. vyd. Praha: Portál; 2007. (in Czech)

Takács L, Sobotková D, Šulcová L. et al. Psychologie $v$ perinatální péči: Praktické otázky a náročné situace. 1. vyd. Praha: Grada Publishing; 2015. (in Czech)

Vaskelyte A, Butkeviciene R. Needs of parents with premature newborns in the neonatal intensive care unit: parents' and nurses' perceptions. Medicina. 2010:46(Suppl 1):43-53.

Vích M. Je možné v ČR udržet kvalitu péče o předčasně narozené děti? Právě probíhajici analýza napoví. 2014 [cited 2016 Jan 5]. Available from: http://www.czf.cz/souory/pnd/tz pnd.pdf (in Czech)

Weis J, Zoffmann V, Egerod I. Enhancing person-centered communication in NICU: a comparative thematic analysis. Nursing in Critical Care. 2013;20(6):287-298.

Whelihaen E. Implementation of interdisciplinary bedside rounds to promote collaboration and family-centered care. The College of St. Scholastica: 2015 [cited 2016 Jan 6]. Available from: http://gradworks.imi.com/36/67/3667778.html

Young J, McCann D, Watson KM, Pitcher A, Bundy R, Greathead D. Negotiation of care for a hospitalised child: nursing perspectives. Journal of Neonatal, Paediatric and Child Health Nursing. 2006;9(3):7-14. 